\title{
PERFORMANCE ANALYSIS OF U19 MALE AND FEMALE SETTERS IN THE BRAZILIAN VOLLEYBALL CHAMPION TEAMS
}

\author{
Cristino J. A. Matias', Jara González-Silva ${ }^{2}$, M. Perla Moreno ${ }^{3}$, and Pablo J. Greco ${ }^{4}$ \\ ${ }^{1}$ Federal University of Jequitinhonha and Mucuri Valleys, Diamantina-MG, Brazil \\ ${ }^{2}$ Faculty of Educational Sciences, Psychology and Sports Sciences, \\ University of Huelva, Huelva, Spain \\ ${ }^{3}$ Faculty of Sports Science, University of Granada, Granada, Spain \\ ${ }^{4}$ Universidade Federal de Minas Gerais, Minas Gerais, Brazil
}

Original scientific paper

DOI: $10.26582 / \mathrm{k} .53 .1 .14$

\begin{abstract}
:
The present study aims to analyse the associations between setting variables and gender (male and female). The study sample consisted of 711 setting actions made by the setters/starters of the champion teams from the Brazilian states of Minas Gerais (MG) and São Paulo (SP); 313 setting actions were observed for the male category and 398 for the female category. Statistical analysis showed that there were gender differences in the following variables: conditions of the setting, number of attackers available for the attack, set tempo, conditions after setting and the set's area. This information is likely to be relevant for the training process of setting, for both males and females.
\end{abstract}

Key words: performance, genders, volleyball, setting, training stages

\section{Introduction}

In volleyball, game actions are divided into two groups of finalists and intermediates. Finalist actions are those through which a point can usually be obtained, including serve, attack, and block (Gil, Claver, Fernández-Echeverría, Moreno, A., $\&$ Moreno, 2016). Oppositely, intermediate actions are those through which it is not usual to obtain a direct point. This group of actions consists of reception, setting, defence and dig (Mesquita, Manso, \& Palao, 2007). Most research has focused on finalist actions because of their relation to obtaining points (Costa, et al., 2017; García-de-Alcaraz, Ortega, \& Palao, 2016). Non-finalist actions serve to link actions, thus giving them an influence over finalist actions, and are fundamental in volleyball as a cyclical and sequential sport (Ugrinowitsch, et al., 2014). There is thus a need to conduct research focused on intermediate actions as well (FernándezEcheverría, Mesquita, González-Silva, Claver, \& Moreno, 2017).

The present study will focus on setting due to its relevance in volleyball. Setting is fundamental to the organization of an attack (Silva, Lacerda, \& João, 2013), and for determining attack efficacy (Bergeles, Barzouka, \& Nikolaidou, 2009).
Ultimately, this means that setting may have an important influence on a team's overall performance (Buscá \& Febrer, 2012). By setting, the setter attempts to provide the teammate attacker with the best position to carry out an attack, in other words, to place him/her in front of the fewest number of blockers (Palao \& Martínez, 2013).

The setter is a specialized player who plays an essential role in the team, often referred to by volleyball specialists as the brain of the team (Matías \& Greco, 2010). This is because the setter is responsible for setting up the team's attacks and counterattacks (Silva, et al., 2013; Zetou, Moustakidis, Tsigillis, \& Komnonakidou 2007); he/she also assumes responsibility for the tactical development of the game when having to make a large number of decisions when attacking (Gil, Moreno, Moreno, García-González, \& del Villar, 2011). Psychologically, the setter must be a person with leadership skills and an initiator of team spirit (Mesquita \& Graça, 2002). From a technical point of view, the setter's ability determines speed and diversity of the team's attack (Mesquita \& Graça, 2002), and chances of making the most of bad receptions (Matias \& Greco, 2013; Papadimitriou, Pashali, Sermaki, Mellas, \& Papas, 2004). Tactically, the 
setter has to set the ball taking into account different defensive formations of the opponent (Matias \& Greco, 2010) to create attack situations that unbalance the blockers (Afonso, Mesquita, Marcelino, \& Silva, 2010).

Out of different volleyball game actions, setting is the first function in play for which specialization occurs on the path of player development (Maia \& Mesquita, 2006; Moutinho, Marques, \& Maia, 2003), and it is typically recommended that it should start at the age between 14 and 16 years (Milistetd, Mesquita, do Nascimiento, \& Sobrinho, 2009). Although specialization begins at the same time for boys and girls, certain gender differences can be observed in setting performance. These differences may be due to differences between genders in terms of anatomy, but also due to the structure of the game, the techniques and tactics used, and the effectiveness of the actions (Costa, Afonso, Brant \& Mesquita, 2012) for the different gender categories.

Despite the importance of setting, few investigations have focused on it. Some, such as Silva, Lacerda, and João (2014), have studied the form of the setter and the actions if this player that determine victory. Other studies have focused on understanding how preceding actions affect setting (Afonso, Esteves, Araújo, Thomas, \& Mesquita, 2012; González-Silva, Moreno, A., FernándezEcheverría, Claver, \& Moreno, 2019), or how the characteristics of this action influence phases of the game (Palao \& Ahrabi-Fard, 2014). Of these investigations, most were conducted at the elite level, with a minority studying training categories (GonzálezSilva, Moreno, Fernández-Echeverría, Claver, \& Moreno, 2016).

On the other hand, gender is an underlying variable in the analysis of sports performance, because it generates certain performance differences. Specifically, in volleyball, these differences are manifested in the anthropometric (Mihalik, et al., 2008) and psychological characteristics of female and male players (Malousaris, et al., 2008), as well as in the structure of the game, the technique and tactics used, and the efficacy of the actions (Costa, et al., 2012).

Given the importance of the setter's performance in volleyball and the fact that most previous studies have focused on elite volleyball rather than young players in various training stages, it is important to conduct studies in this area. In addition, it is appropriate to consider the gender in the study, due to the existing differences depending on this variable. Therefore, the present study aims to analyse the associations between setting variables and gender (male and female) in volleyball of U-19 category.

\section{Methods}

\section{Sample}

The study sample consisted of 711 setting actions, of which 313 were from the male category and 398 from the female category, carried out by the setters/starters of the champion teams from the states of Minas Gerais (MG) and São Paulo (SP) in Brazil. Therefore, the sample comprised four setters, two male and two female.

Observations were made from two matches from the male category, and two matches from the female category. For each category, one game was observed from the end of each of the MG and SP state championships.

This study takes into account the standards established by the National Health Council of Brazil for studies using human participants and was approved by the Ethics Committee for Studies of the Federal University of Minas Gerais (UFMG), see $n^{\circ}$ ETIC 165/08. The participants agreed to participate voluntarily in our study and accepted the absence of any financial reimbursement. Acknowledgement of the right to withdraw from participation without implication was also collected, and we guaranteed that participants would remain anonymous. The objective of the study was explained to and understood by the participants. Finally, the respective results were presented to each of the participants. Participants recorded their agreement to participate by signing a Terms of Free and Clarified Consent form.

\section{Variables}

The variables considered in the study are presented below:

Setting conditions: understood as the zone and delivery characteristics of the ball for the performance of the set. The categories were: excellent, the ball reaches the attack zone and allows for a jump set with all the attack options; acceptable, the ball reaches the attack zone but only allows for a standing set with just several attack options; not acceptable, the ball reaches the attack or defence zone and limits the number of attack combinations available (Afonso, et al., 2012).

Number of attackers available for the attack: defined as the number of attackers available to perform the attack at the time of setting. The categories were: one, only one player is available to perform the attack; two, two players are available to perform the attack; three, three players are available to perform the attack; four, four players are available to perform the attack (Matias \& Greco 2011a; 2011b).

Tempo of set: "defined as the interaction between the moment when the setter made contact with the ball and the start of the attackers' approach" 
(Castro \& Mesquita, 2010: 199). An adaptation of the criteria Afonso et al. (2010) and Papadimitriou et al. (2004), used also in the study by GonzálezSilva, Fernández-Echeverría, Conejero, and Moreno (2020), establishes three tempos considering the position of the attacker once the ball gets to the setter: first tempo, the attacker is in the air; second tempo, the attacker is making the penultimate stride of the approach; third tempo, the attacker has not started the attack approach, and setter attack, the setter makes the attack on the second contact.

Conditions after setting: defined as the quantitative attacker to blocker/s ratio as a result of the setting. The categories were: perfect, setting results in an attacker-blocker ratio of 1:0, that is, no block has been formed; good, setting results in an attackerblocker ratio of 1:1, that is, a single opponent jumps to block; bad, setting results in an attacker-blocker ratio of $1: 2$ or 1:3, that is, two or three opponents jump to the block (adapted from Moreno, Moreno, Ureña, Iglesias, \& Del Villar, 2008).

Setting outcome: understood as the result of the final attack process, that is, the outcome of the attack made by the player to whom the setting was sent. The categories were: good, the attack limits opposing team's combinations of offensive plays or a first tempo in the construction of a counterattack; $b a d$, the attack does not hinder the opposing team's construction of a counterattack and provides them with attack options; point, the team scores a point by a direct attack or by the opposing team's inability to defend (Coleman, 1975).

Setting's area, understood as the zone of the court from where the attacker performs the attack (Figure 1). The criteria used by Papadimitriou et al. (2004) were the following: zone 1, 2, 3, 4, and 6.

Player to whom the setting was sent: understood as the function of the player function who carries out the attack. Similarly to those used by other investigations (Maia \& Mesquita, 2006; Stankoviae, Ruiz-Llamanas, Periae, \& Quiroga, 2018), the categories were: receiver, the attack is made by the receiving player; middle blocker, the attack is made by the middle blocker; opposite, the attack is performed by the opposite hitter; setter, the attack is made by the setter. female.

Gender, differentiates two genders, male and

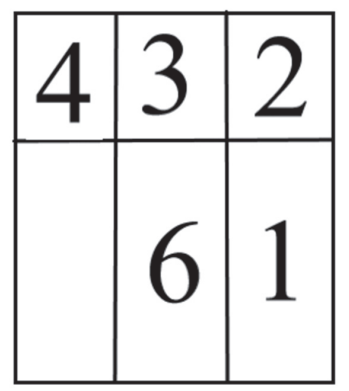

Figure 1. Setting's areas.

\section{Procedure and data gathering}

The matches, which were the finals of the championships, were recorded to MiniDVD format (with the camera fixed behind the game area, specifically behind the defence zone, which allowed for recording of the entire court). Later these recordings were transformed to MPG format by connecting the video recorder (Canon ZR-300) to the computer by means of the firewire connection. A database for game analysis was created using the Simi Scout behaviour analysis software (Matias, Costa, Lima, Greco, \& Greco, 2005) after video capture and the inclusion of the analysis variables.

\section{Reliability}

One observer was trained to carry out the observation, to guarantee the reliability of it. Different training sessions surpass $10 \%$ of the sample (Losada \& Manolov, 2015). In all the variables, values of .81 of the Cohen's Kappa were obtained (Fleiss, Levin, \& Paik, 2003).

\section{Statistical analysis}

The association between the study variables and gender (male and female) was verified by the inferential analysis. Specifically, contingency tables, Chi-Square, and Cramer's V values, with the correction of Monte Carlo, were included. The value of $p<.05$ was the value of significance to be considered. The statistical software package SPSS was used for conducting the analyses.

\section{Results}

A significant association was obtained between gender and setting conditions $\left(\chi^{2}=22.500\right.$; Cramer's $\mathrm{V}=.178 ; \mathrm{p}<.001)$. Contributed positively: the male gender with excellent setting conditions and the female gender with acceptable setting conditions (Table 1).

A significant association was obtained between gender and number of attackers available for the attack $\left(\chi^{2}=142.174\right.$; Cramer's V=.447; $\left.\mathrm{p}<.001\right)$. Contributed positively: the male gender with four available players, and the female gender with one or two available players (Table 2).

A significant association was obtained between gender and tempo of set $\left(\chi^{2}=8.641\right.$; Cramer's $\mathrm{V}=.118$; $\mathrm{p}=.034)$. Contributed positively: the male gender with second tempo, and the female gender with third tempo (Table 3).

A significant association was obtained between gender and conditions after setting $\left(\chi^{2}=11.343\right.$; Cramer's V=.126; $\mathrm{p}=.003)$. Contributed positively: the male gender with good, and the female gender with bad (Table 4).

Statistical analysis was not conducted to test the associations between gender and setting outcome $\left(\chi^{2}=5.084\right.$; Cramer's V=.085; $\left.\mathrm{p}=.166\right)$. 
Table 1. Contingency table gender-setting conditions

\begin{tabular}{|c|c|c|c|c|c|}
\hline & & & & Gender & \\
\hline & & & Male & Female & Total \\
\hline \multirow{9}{*}{$\begin{array}{l}\text { Setting } \\
\text { conditions }\end{array}$} & \multirow{3}{*}{ Excellent } & Count & 174 & 160 & 334 \\
\hline & & Expected frequency & 147.0 & 187.0 & 334.0 \\
\hline & & Adjusted residuals & 4.1 & -4.1 & \\
\hline & \multirow{3}{*}{ Acceptable } & Count & 19 & 58 & 77 \\
\hline & & Expected frequency & 33.9 & 43.1 & 77.0 \\
\hline & & Adjusted residuals & -3.6 & 3.6 & \\
\hline & \multirow{3}{*}{ Not acceptable } & Count & 120 & 180 & 300 \\
\hline & & Expected frequency & 132.1 & 167.9 & 300.0 \\
\hline & & Adjusted residuals & -1.8 & 1.8 & \\
\hline \multirow{2}{*}{ Total } & & Count & 313 & 398 & 711 \\
\hline & & Expected frequency & 313.0 & 398.0 & 711.0 \\
\hline
\end{tabular}

No cells $(.0 \%)$ have an expected frequency less than 5 . The minimal expected frequency is 33.90 .

Table 2. Contingency table gender - number of attackers available for the attack

\begin{tabular}{|c|c|c|c|c|c|}
\hline & & & & Gender & \\
\hline & & & Male & Female & Total \\
\hline \multirow{12}{*}{$\begin{array}{l}\text { Number of } \\
\text { attackers } \\
\text { available for the } \\
\text { attack }\end{array}$} & \multirow{3}{*}{ One } & Count & 21 & 60 & 81 \\
\hline & & Expected frequency & 35.7 & 45.3 & 81.0 \\
\hline & & Adjusted residuals & -3.5 & 3.5 & \\
\hline & \multirow{3}{*}{ Two } & Count & 71 & 158 & 229 \\
\hline & & Expected frequency & 100.8 & 128.2 & 229.0 \\
\hline & & Adjusted residuals & -4.8 & 4.8 & \\
\hline & \multirow{3}{*}{ Three } & Count & 117 & 174 & 291 \\
\hline & & Expected frequency & 128.1 & 162.9 & 291.0 \\
\hline & & Adjusted residuals & -1.7 & 1.7 & \\
\hline & \multirow{3}{*}{ Four } & Count & 104 & 6 & 110 \\
\hline & & Expected frequency & 48.8 & 61.6 & 110.0 \\
\hline & & Adjusted residuals & 11.6 & -11.6 & \\
\hline \multirow{2}{*}{\multicolumn{2}{|c|}{ Total }} & Count & 313 & 110 & 711 \\
\hline & & Expected frequency & 313.0 & 110.0 & 711.0 \\
\hline
\end{tabular}

No cells $(.0 \%)$ have an expected frequency less than 5 . The minimal expected frequency is 35.66 .

Table 3. Contingency table gender - tempo of set

\begin{tabular}{|c|c|c|c|c|c|}
\hline & & & \multicolumn{3}{|c|}{ Gender } \\
\hline & & & Male & Female & Total \\
\hline \multirow{12}{*}{ Tempo of set } & \multirow{3}{*}{$1^{\circ}$ tempo } & Count & 100 & 114 & 214 \\
\hline & & Expected frequency & 94.2 & 119.8 & 214.0 \\
\hline & & Adjusted residuals & 1.0 & -1.0 & \\
\hline & \multirow{3}{*}{$2^{\circ}$ tempo } & Count & 80 & 74 & 154 \\
\hline & & Expected frequency & 67.8 & 86.2 & 154.0 \\
\hline & & Adjusted residuals & 2.2 & -2.2 & \\
\hline & \multirow{3}{*}{$3^{\circ}$ tempo } & Count & 125 & 100 & 325 \\
\hline & & Expected frequency & 143.1 & 181.9 & 325.0 \\
\hline & & Adjusted residuals & -2.7 & 2.7 & \\
\hline & \multirow{3}{*}{ Setter attack } & Count & 8 & 10 & 18 \\
\hline & & Expected frequency & 7.9 & 10.1 & 18.0 \\
\hline & & Adjusted residuals & .0 & .0 & \\
\hline \multirow{2}{*}{ Total } & & Count & 313 & 398 & 711 \\
\hline & & Expected frequency & 313.0 & 398.0 & 711.0 \\
\hline
\end{tabular}

No cells $(.0 \%)$ have an expected frequency less than 5 . The minimal expected frequency is 7.92 
Table 4. Contingency table gender - conditions after setting

\begin{tabular}{|c|c|c|c|c|c|}
\hline & & & & Gender & \\
\hline & & & Male & Female & Total \\
\hline \multirow{9}{*}{$\begin{array}{l}\text { Conditions after } \\
\text { setting }\end{array}$} & \multirow{3}{*}{ Bad } & Count & 190 & 289 & 479 \\
\hline & & Expected frequency & 210 & 268.1 & 479.0 \\
\hline & & Adjusted residuals & -3.4 & 3.4 & \\
\hline & \multirow{3}{*}{ Good } & Count & 105 & 94 & 199 \\
\hline & & Expected frequency & 87.6 & 111.4 & 199.0 \\
\hline & & Adjusted residuals & 2.9 & $-2,9$ & \\
\hline & \multirow{3}{*}{ Perfect } & Count & 18 & 15 & 33 \\
\hline & & Expected frequency & 14.5 & 18.5 & 33.0 \\
\hline & & Adjusted residuals & 1.2 & -1.2 & \\
\hline \multirow{2}{*}{ Total } & & Count & 313 & 398 & 711 \\
\hline & & Expected frequency & 313.0 & 398.0 & 711.0 \\
\hline
\end{tabular}

No cells $(.0 \%)$ have an expected frequency less than 5 . The minimal expected frequency is 14.53

Table 5. Contingency table gender - setting's area

\begin{tabular}{|c|c|c|c|c|c|}
\hline & & & \multicolumn{3}{|c|}{ Gender } \\
\hline & & & Male & Female & Total \\
\hline \multirow{15}{*}{ Setting's area } & \multirow{3}{*}{ Zone one } & Count & 33 & 16 & 49 \\
\hline & & Expected frequency & 21.6 & 27.4 & 49.0 \\
\hline & & Adjusted residuals & 3.4 & -3.4 & \\
\hline & \multirow{3}{*}{ Zone two } & Count & 66 & 117 & 183 \\
\hline & & Expected frequency & 80.6 & 102.5 & 183.0 \\
\hline & & Adjusted residuals & -2.5 & 2.5 & \\
\hline & \multirow{3}{*}{ Zone three } & Count & 74 & 82 & 156 \\
\hline & & Expected frequency & 68.7 & 87.3 & 156.0 \\
\hline & & Adjusted residuals & 1.0 & -1.0 & \\
\hline & \multirow{3}{*}{ Zone four } & Count & 119 & 163 & 282 \\
\hline & & Expected frequency & 124.1 & 157.9 & 282.0 \\
\hline & & Adjusted residuals & -.8 & .8 & \\
\hline & \multirow{3}{*}{ Zone six } & Count & 21 & 20 & 41 \\
\hline & & Expected frequency & 18.0 & 23.0 & 41.0 \\
\hline & & Adjusted residuals & 1.0 & -1.0 & \\
\hline \multirow{2}{*}{ Total } & & Count & 313 & 398 & 711 \\
\hline & & Expected frequency & 313.0 & 398.0 & 711.0 \\
\hline
\end{tabular}

No cells $(.0 \%)$ have an expected frequency less than 5 . The minimal expected frequency is 18.05 .

A significant association was obtained between gender and setting's area $\left(\chi^{2}=17.499\right.$; Cramer's $\mathrm{V}=.157 ; \mathrm{p}=.002)$. Contributed positively: the male gender with zone one, and the female gender with zone two (Table 5).

Statistical analysis was not conducted to test the associations between gender and player to whom the setting was sent $\left(\chi^{2}=.1 .109\right.$; Cramer's $V=.039$; $\mathrm{p}=.775$ ).

\section{Discussion and conclusions}

The present study aimed to analyse the associations between setting variables and gender (male and female) in U-19 volleyball.

The results indicated that the variables associated with gender were: setting conditions, number of attackers available for the attack, tempo of set, conditions after setting and seting's area.

The results indicated a significant association between gender and setting conditions. For males, it was a greater frequency of excellent setting conditions than would be expected by random, while for females it was a greater frequency of acceptable setting conditions than would be expected by random.

Consistent with these results, several previous studies, such as Gil et al. (2011), have shown that for males in various training stages there was a greater frequency of excellent setting conditions than would be expected by random, which allowed for setters to have all the possible attack options. Gil et al. (2011) also found similar results for females, for 
whom there was a greater frequency of acceptable setting conditions as would be expected by random, and which did not allow for setters to have all the possible attack options.

Due to the specific characteristics of the game sequence in volleyball, the ball reception and setting are related (Silva, et al., 2013). It is, therefore, necessary to perform a high-quality reception (Marelić, Rešetar, \& Janković, 2004; Papadimitriou, et al., 2004) to send the ball to an excellent setting area. As setting efficacy decreases when made from unacceptable areas (Afonso, et al., 2010; Barzouka, Nikolaidou, Malousaris, \& Bergeles 2006), the quality of reception can be considered to determine setting efficacy (Afonso, et al., 2012; González-Silva, et al., 2016).

This implies that it is necessary to emphasize high-quality receptions targeted at excellent setting zones when training players, and specifically female players, to give setters an advantage.

For the association between gender and the number of attackers available for the attack, our results showed a significant association. For males, it was a greater frequency of four available players than expected by random. For females, it was a greater frequency of one or two available players for the attack than expected by random.

Only a small number of studies have analysed the number of players available for the attack, and of these most have considered the availability of the middle blocker (Afonso \& Mesquita, 2011; Matias $\&$ Greco, 2011a, 2011b). One investigation of elite men's volleyball (Castro, Souza, \& Mesquita, 2011), aimed at identifying the performance indicators that predicted the efficacy of attack in complex II, included the number of available players for the attack as a study variable. This study showed that in this complex, two or three attackers were available to make an attack. Matias and Greco (2011a), in a study of male and female setters who were champions of the Brazilian Superliga, found that the quality of the first contact determined the use of more attackers, the use of attack tempos of different speeds, and the use of different offensive sectors of the court.

Speaking in the most general terms of performance indicators, the level of play tends to be higher in the male gender than in the female gender. The results show that setting to the back zones is more often used as an attack option in males, meaning that a greater number of players can be available to perform the attack.

The results indicated a significant association between gender and the tempo of setting. For the male gender, it was a greater frequency of second tempo than expected by random, while for the female gender it was a greater frequency of third tempo than expected by random.
Similar results were found by Costa et al. (2012), in the study which aimed to understand differences between male and female players in different game actions of young volleyball players. Here, the male players were shown to play a faster game than the female peers.

Since blockers are of a higher level in the male gender compared to the female gender (Zetou, et al., 2007), therefore, to avoid a good block formation, male players need to play quickly (Palao \& Martínez, 2013), which may explain gender differences in terms of game speed.

A significant association was obtained between gender and setting's outcome. For males, it was a greater frequency of a point outcome than expected by random, while for females, it was a greater frequency of a good outcome (the attack prevents the opposing team's counterattack combination or the first tempo for the counterattack) than expected by random.

In line with our results, previous investigations have also found significant differences in the attack between men and women (João, Leite, Mesquita \& Sampaio, 2010). Forthomme and Corisier (2005) showed that women performed less powerful attacks than men, which may be one of the reasons why in our study the male gender was more strongly associated with point outcome, while the female gender was not.

This finding may be due to the faster game speed in the male gender (Costa, et al., 2012). An increase in attack speed decreases the reaction time of the opposing defence (Costa, et al., 2010) and increases imbalance (Zetou, et al., 2007). The performance of fast attacks (first and second tempos) thus increases the chance of scoring a point (Costa, et al., 2010) and may well explain our results.

Finally, for the association between gender and the zone to which the setting is sent, our results showed that there was a greater frequency than expected by random of settings sent to zone 1 for males, and a larger frequency than expected by random of settings sent to zone 2 for females.

Palao, Santos, and Ureña (2007) conducted a study of elite players (male and female) in which they wanted to understand attack patterns at the elite level. At the same time, these researchers studied how this affected execution and performance. The authors argued that the player who participated most in attacks was the opposite. The specific position of this player is in zone 2 when he/ she is forward and zone 1 when he/she is a defender (Gil, Moreno, M.P, Moreno, García-González, \& Del Villar, 2010).

A research conducted in the girl's infant-youth category (Gouvea \& Lopes, 2008) has highlighted the increase in the versatility of the opposites, and with this an increased confidence in them felt by 
setters. Additionally, previous studies of both males and females (Cesar \& Mesquita, 2006; Papadimitriou, et al., 2004) show that the opposites perform well in attack.

In the Brazilian men's youth gender, we found that it was more frequent than expected randomly that: the balls reached an excellent zone, four players were available for the attack, the conditions for the completion of the setting were good, the outcome of the setting was a point, and the settings were sent to zone one. On the contrary, in the female gender, it was more frequent than expected randomly that: the balls reached an acceptable zone, that only one or two players were available for the attack, the conditions for the completion of the setting were $\mathrm{bad}$, the outcome of the setting was good but point not scored, and the settings were sent to zone two.

The results confirmed differences in the behavior of the Brazilian U-19 setters that depended on their gender. These results indicate that the standard of male setters is slightly higher than that of the female setters.

This information is likely to be useful for coaches as they offer gender specific guidelines for the orientation of the training process for setting.

\section{References}

Afonso, J., Esteves, F., Araújo, R., Thomas, L., \& Mesquita, I. (2012). Tactical determinants of setting zone in elite men's volleyball. Journal of Sports Science and Medicine, 11, 64-70.

Afonso, J., \& Mesquita, I. (2011). Determinants of block cohesiveness and attack efficacy in highlevel women's volleyball. European Journal of Sport Science, 11(1), 69-75.

Afonso, J., Mesquita, I., Marcelino, J., \& Silva, J. (2010). Analysis of the setter's tactical action in high-performance women's volleyball. Kinesiology, 42(1), 82-89.

Barzouka, K., Nikolaidou, M., Malousaris, G., \& Bergeles, N. (2006). Performance excellence of male setters and attackers in Complex I and II on volleyball teams in the 2004 Olympic Games. International Journal of Volleyball Research, 9(1), 19-24.

Bergeles, N., Barzouka, K., \& Nikolaidou, M.E. (2009). Performance of male and female setters and attackers on Olympic-level volleyball teams. International Journal of Performance Analysis of Sport, 9, 141-148.

Buscà, B., \& Febrer, J. (2012). Temporal fight between the middle blocker and the setter in high level volleyball. Revista Internacional de Medicina y Ciencias de la Actividad Física y el Deporte, 12(46), 313-327.

Castro, J., \& Mesquita, I (2010). Analysis of the attack tempo determinants in volleyball's complex - A study on elite male teams. International Journal of Performance Analysis in Sport, 10(3), 197-206.

Castro, J., Souza, A., \& Mesquita, I. (2011). Attack efficacy in volleyball: Elite male team. Perceptual and Motor Skills, 113(2), 395-408.

César, B., \& Mesquita, I. (2006). Caracterização do ataque do jogador oposto em função do complexo do jogo, do tempo e do efeito do ataque: estudo aplicado no voleibol feminino de elite. [Characterization of the opposite player's attack according to the Rally Phase, Attack-tempo and Effect of attack: Study applied in top level female volleyball. In Portuguese.] Revista Brasiliera de Educacao Física e Esporte, 20(1), 59-69.

Coleman, J.E. (1975). A statistical evaluation of selected volleyball techniques at the 1974 World's Volleyball Championships. (Thesis Physical Education). Brigham: Young University.

Costa, C., Afonso, J., Brant, E., \& Mesquita, I. (2012). Differences in game patterns between male and female youth volleyball. Kinesiology, 44(1), 60-66.

Costa, G.C., Castro, H., Evangelista, B., Malheiros, L., Greco, P.J., \& Ugrinowitsch, H. (2017). Predicting factors of Zone 4 attack in volleyball. Perceptual and Motor Skills, 124(3), 621-633.

Costa, G., Mesquita, I., Greco, P., Ferreria, N., \& Moraes, J. (2010). Relación entre el tipo, tiempo y el efecto del ataque en el voleibol femenino juvenil de alto nivel de competición. [Relationship between type, time and effect of attack on high-level junior women's volleyball in. In Spanish.] Motricidad - European Journal of Human Movement, 24, 121-132.

Fernández-Echeverría, C., Mesquita, I., González-Silva, J., Claver, F., \& Moreno, M.P. (2017). Match analysis within the coaching process: A critical tool to improve coach efficacy. International Journal of Performance Analysisi of Sport, 17(1-2), 149-163.

Fleiss, J., Levin, B., \& Paik, M. (2003). Statistical methods for rates and proportions. New York: John Wiley \& Sons.

Forthomme, B., \& Corisier, J. (2005). Factors correlated with volleyball spike velocity. The American Journal of Sport Medicine, 33, 52-58.

García-de-Alcaraz, A., Ortega, E., \& Palao, J.M. (2016). Effect of age group on technical-tactical performance profile of the serve in men's volleyball. Perceptual and Motor Skills, 123(2), 508-525. 
Gil, A., Claver, F., Fernández-Echeverría, C., Moreno, A., \& Moreno, M.P. (2016) Análisis comparativo del saque en voleibol entre los campeonatos de España 2005-2010. [Comparative analysis of the serve in volleyball between the Spanish championshios 2005-2010. In Spanish.] Revista Internacional de Medicina y Ciencias de la Actividad Física y el Deporte, 16(62), 439-456.

Gil, A., Moreno, M.P., Moreno, A., García-González, L., \& Del Villar, F. (2010), Caracterización del saque de voleibol en categorías de formación atendiendo a la función del juego. [Characterization of the volleyball serve in training categories according to the function of the game. In Spanish.] Revista Internacional de Deportes Colectivos, 6, 37-61.

Gil, A., Moreno, M.P., Moreno, D., García González, L., \& Del Villar, F. (2011). Estudio del saque en jóvenes jugadores/ as de voleibol, considerando la eficacia y función en juego. [Study of serving volleyball players, taking into account efficacy and role play. In Spanish.] Retos. Nuevas tendencias en Educación Física, Deporte y Recreación, 19, 19-24.

González-Silva, J., Fernández-Echeverría, C., Conejero, M., \& Moreno, M.P. (2020). Characteristics of serve, reception and set that determine the setting efficacy in men's volleyball. Frontiers in Psychology, 11, 222.

González-Silva, J., Moreno, A., Fernández-Echeverría, C., Claver, F., \& Moreno, M.P. 2016). Analyses of setting efficacy in young male and female volleyball players. Journal of Human Kinetics, 53, 189-200.

González-Silva, J., Moreno, A., Fernández-Echeverría, C., Claver, F., \& Moreno, M.P. (2018). Variables predictoras de la colocación en el complejo de defensa en voleibol. [Variables predictors of the set in the defence complex in volleyball. In Spanish.] Revista Internacional de Medicina y Ciencias de la Actividad Física y el Deporte.

Gouvea, F.L. \& Lopes, M.B. (2008). Incidence do ataque no voleibol infanto-juvenil femenino. [Incidence of attack in girls' volleyball. In Portuguese.] Movimiento \& Percepçao, 9(12), 168-183.

João, P.V., Leite, N., Mesquita, I., \& Sampaio, J. (2010). Sex differences in discriminative power of volleyball gamerelated statistics. Perceptual and Motor Skills, 111(3), 893-900.

Losada, J.L., \& Manolov, R. (2015). The process of basic training, applied training, maintaining the performance of an observer. Quality and Quantity, 49, 339-347.

Maia, N., \& Mesquita, I. (2006). Estudo das zonas e eficácia da recepção em função do jogador recebedor no voleibol sénior feminino. [Study of the zones and effectiveness of reception according to the receiving player in women's senior volleyball. In Portuguese.] Revista Brasileira de Educação Física e Esportes, 20(4), 257-270.

Malousaris, G.G., Bergeles, N.K., Barzouka, K.G., Bayios, I.A., Nassis, G.P., \& Koskolou, M.D. (2008). Somatotype, size and body composition of competitive female volleyball players. Journal of Science and Medicine in Sport, 11(3), 337-344.

Marelić, N., Rešetar, T., \& Janković, V. (2004). Discriminant analysis of the sets won and the sets lost by one team in A1 Italian volleyball league - A case study. Kinesiology, 36(1), 75-82.

Matias, C.J.A.S., Costa, H., Lima, C.O.V., Greco, F.L., \& Greco, P.J. (2005). Conhecimento tático declarativo: uma análise no campeonato brasileiro de seleções masculinas juvenis de voleibol. [Declarative tactical knowledge: An analysis in the Brazilian championships of youth volleyball teams. In Portuguese.] Revista Mineira de Educação Física, 2, 1-10.

Matias C.J.A.S., \& Greco P.J. (2010). A grelha do conhecimento tático-estratégico dos levantadores: estudo realizado com os campeões dos escalões de base e da Superliga de voleibol. [The grid of tactical-strategic knowledge of lifters: A study conducted with the champions of the base echelons and the volleyball Superliga. In Portuguese.] Cuaderno de Educação Física e Esporte, 25(3), 513-535.

Matias C.J.A.S., \& Greco P.J. (2011a). Análise da organização ofensiva dos levantadores campeões da Superliga de voleibol. [Analysis of the offensive organization of the volleyball Super league champions. In Portuguese.] Revista Brasileira de Ciências do Esporte, 33(4), 1007-1028.

Matias C.J.A.S., \& Greco P.J. (2011b). Conhecimento tático-estratégico dos levantadores brasileiros campeões de voleibol: da formação ao alto nível. [Tactical-strategic knowledge of Brazilian volleyball champions: From high-level training. In Portuguese.] Revista Brasileira de Educação Física e Esporte, 24(1), 69-78.

Matias, C.J.A.S., \& Greco, P.J. (2013). O conhecimento táctico declarative dos levantadores campeoes de voleibol. [The tactical declarative knowledge of the volleyball champions setters. In Portuguese.] Motriz, 19(1), 185-194.

Mesquita, I., \& Graça, A. (2002). Probing the strategic knowledge of an elite volleyball setter: A case study. International Journal of Volleyball Research, 5, 6-12.

Mesquita, I., Manso, F.D., \& Palao, J.M. (2007). Defensive participation and efficacy of the libero in volleyball. Journal of Human Movement Studies, 52, 95-107.

Mihalik, J.P., Libby, J.J., Battaglini, C.L., \& McMurray, R.G. (2008). Comparing short-term complex and compound training programs on vertical jump height and power output. Journal of Strength and Conditional Research, 22(1), 47-53.

Milistetd, M., Mesquita, I., do Nascimiento, J.V., \& Sobrinho, A.P. (2009). A concepçâo de treinadores "experts" Brasileiros acerca do processo de especializaçâo funcional na formaçâo desportiva a longo prazo do jogador de voleibol. [Brazillian expert coaches' conceptions about functional specialization process in long-term sport formation of volleyball players. In Portuguese.] Revista da Educaçâo Física/UEM, 20(2), 161-170. 
Moreno, M.P., Moreno, A., Ureña, A., Iglesias, D., \& Del Villar, F. (2008). Application of mentoring through reflection in female setters of the Spanish National Volleyball Team: A case study. International Journal of Sport Psychology, 39(1), 59-36.

Moutinho, C., Marques, A. \& Maia, J. (2003). Estudo da estrutura interna das acoçoes da distribuiçao em equipas de Voleibol de alto nivel de rendimento. [Study of the internal structure of the actions of the distribution in volleyball teams of high-level performance. In Portuguese.] In I. Mesquita, C. Moutinho y R. Faria (Eds.), Investigaçao em Voleibol - Estudos Ibéricos (pp. 107-129). FCDEF-UP.

Palao, J.M., \& Ahrabi-Fard, I. (2014). Effect of jump set usage on side-out phase in women's college volleyball. Journal of Sport and Human Performance, 2(3), 1-10.

Palao, J.M., \& Martínez, S. (2013). Utilización de la colocación en salto en función del nivel de competición en voleibol masculino. [Use of jump set in relationship to the competition level in male volleyball.] Revista Euroamericana de Ciencias del Deporte, 2(1), 43-49.

Palao, J., Santos, J., \& Ureña, A. (2007). Effect of the manner of spike execution on spike performance in volleyball. International Journal of Performance Analysis in Sport, 7, 126-138.

Papadimitriou, K., Pashali, E., Sermaki, I., Mellas, S., \& Papas, M. (2004). The effect of the opponents' serves on the offensive actions of Greek setters in volleyball games. International Journal of Performance Analysis in Sport, 4(1), 23-33.

Silva, M., Lacerda, D., \& João, V. (2013). Match analysis of discrimination skills according to the setter attack zone position in high level volleyball. International Journal of Performance Analysis in Sport, 13, 452-460.

Silva, M., Lacerda, D., \& João, V. (2014). Match analysis of discrimination skills according to the setter defence zone position in high level volleyball. International Journal of Performance Analysis in Sport, 14, 463-472.

Stankoviae, M., Ruiz-Llamanas, G., Periae, D., \& Quiroga-Escudero, M. (2018). Analysis of serve characteristics under rules tested at Volleyball Men's Under 23 World Championship. Retos. Nuevas tendencias en Educación Física, deporte y Recreación, 33, 20-26.

Ugrinowitsch, H., Lage, G., Santos-Naves, S.P., Dutra, L., Carvalho, M.F., Ugrinowitsch, A., \& Benda., R. (2014). Transition I efficiency and victory in volleyball matches. Motriz, 20(1), 42-46.

Zetou, E., Moustakidis, A., Tsigilis, N., \& Komninakidou, A. (2007). Does effectiveness of skill in Complex I predict win in men's Olympic volleyball games? Journal of Quantitative Analysis in Sport, 3(4), 1559-1570.

\author{
Submitted: October 29, 2018 \\ Accepted: February 22, 2021 \\ Published Online First: May 20, 2021 \\ Correspondence to: \\ Prof. Jara González Silva, Ph.D. \\ Faculty of Educational Sciences, Psychology and \\ Sports Sciences \\ Av. De las Fuerzas Armadas, s/n \\ 21007, Huelva, Spain \\ Tel.: (+43) 654988080 \\ E-mail: jara.gonzalez@ddi.uhu.es
}

\title{
Acknowledgements
}

This study was made possible thanks to the contribution of the [Conselho Nacional de Desenvolvimento Científico e Tecnológico (CNPq)], and [Fundação de Amparo à Pesquisa do Estado de Minas Gerais (Fapemig)]. 